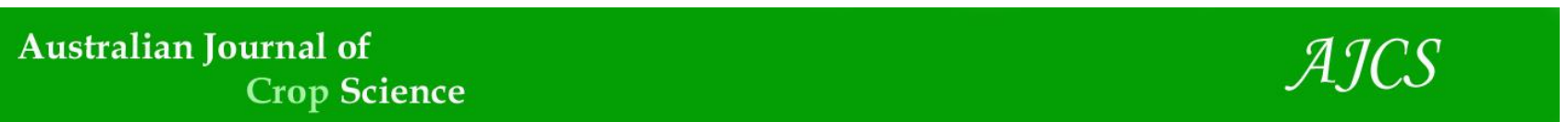

AJCS 15(04):553-558 (2021)

ISSN:1835-2707

doi: 10.21475/ajcs.21.15.04.p2858

\title{
Production of pout pepper (Capsicum chinense) under irrigation depths and nitrogen doses in the Brazilian Cerrado
}

\author{
Juliane de Souza Beltrão ${ }^{1}$, Marcio Koetz ${ }^{1}$, Edna Maria Bonfim-Silva ${ }^{1 *}$, Tonny José Araújo da \\ Silva ${ }^{1}$, Jefferson Vieira José ${ }^{2}$
}

${ }^{1}$ Federal University of Rondonópolis, UFR, Institute of Agricultural and Technological Sciences, 5055, Students

Avenue, Rondonópolis, 78.735-901, Brazil

${ }^{2}$ Multidisciplinary Center, Federal University of Acre, Cruzeiro do Sul, AC 69895-000, Brazil

\section{*Corresponding author: embonfim@hotmail.com}

\begin{abstract}
Correct management of water and fertilizers can enable the profitable and ecologically correct cultivation of pout pepper (Capsicum chinense). In this context, the objective of this study was to assess the effect of drip irrigation depths and nitrogen doses on the cultivation of pout pepper in a Latossolo Vermelho (Oxisol) of the Cerrado region. The experiment was conducted in the field in a randomized block design, at the Federal University of Mato Grosso -Campus of Rondonópolis. The treatments were five irrigation depths $\left(40,60,80,100\right.$ and $120 \%$ of ETc) and five nitrogen doses $\left(0,60,120,180\right.$ and $\left.240 \mathrm{~kg} \mathrm{ha}^{-1}\right)$, with 4 replicates. Fresh and dry weights of fruits, number of fruits, plant yield and water productivity were analyzed. Nitrogen fertilization caused significant differences in fresh and dry weights of fruits ( 873.95 and $\left.133.03 \mathrm{~g} \mathrm{plant}^{-1}\right)$, respectively, as well as in the number of fruits (319.05 fruits plant $\left.^{-1}\right)$ and plant yield $\left(14.9 \mathrm{t} \mathrm{ha}^{-1}\right)$. Water productivity showed a response surface with a stationary point of minimum $\left(7.13 \mathrm{~kg} \mathrm{~L}^{-1}\right)$. Adequate doses of nitrogen and irrigation depths promote good development of pout pepper cultivated in Latossolo Vermelho (Oxisol) of the Cerrado region.
\end{abstract}

Keywords: Family farming; BRS Moema; soil fertility; localized irrigation; evapotranspiration.

Abbreviations: Al_aluminum; Ca_calcium; CV_coefficient of variation; CEC_cation exchange capacity; DWF_dry weight of fruits per plant; ETC_crop evapotranspiration; ETo_reference evapotranspiration; FWF_fresh weight of fruits per plant; $H_{-}$hydrogen; K_potassium; Kc_crop coefficient; Mg_magnesium; NF_number of fruits per plant; OM_organic matter; P_phosphorus; PY_plant yield; TRNV_total relative neutralizing power; $S_{\text {_ }}$ sum of bases; $V_{-}$base saturation; WP_water productivity.

\section{Introduction}

The cultivation of alternative crops can be a very profitable economic activity for small producers. As high levels of agricultural technology and skilled labor are not required, their cultivation is the most adopted (Heinrich et al., 2015; Almeida et al., 2017). Among a wide range of species, the cultivation and processing of peppers of the genus Capsicum is an option that can provide the producer with good income in a small planting area (Carvalho et al., 2008; Serenini \& Malysz, 2014).

Among the species of the genus Capsicum, pout pepper (Capsicum chinense) has stood out in the pepper market due to its main characteristic, the absence of pungency in the fruits, which results in low spiciness, combined with a remarkable flavor (; Ribeiro et al., 2008). Its peculiar characteristics favor a differentiated use of the fruits in several product lines in the food industry, being well accepted by consumers who appreciate the taste of peppers without wanting to feel the burning sensation (Bosland \& Votava, 2000; Macedo, 2015).

Proper management of essential nutrients, such as nitrogen (N), in the cultivation of pout pepper is essential for plants to complete their life cycle expressing their maximum production potential, with fruits that meet the marketing standards. In the literature, there is scarce information on the recommendation of $\mathrm{N}$ fertilization in Cerrado soils, which leads to the need for research to study its supply to plants in order to obtain its recommendation and aiming at rational use of $\mathrm{N}$ sources (Souza et al., 2011; Primavesi, 2002).

For the effective absorption of essential nutrients to occur, adequate supply of water to plants is essential and can be carried out in several ways by the producer. Fruits that contain water in most their composition, such as peppers, require a large volume of water. In the field, water supply becomes more feasible and practical with the adoption of irrigation systems (Mengel \& Kirkby, 2001; Taiz et al, 2017). Among the existing types, the localized irrigation system is the one with highest efficiency in water application, because it moistens only part of the soil surface, but its use is not yet widespread in the cultivation of peppers. Although one of the main limitations is its high initial cost, studies using a localized irrigation system are important since there is an increase in the saving of water, fertilizers (fertigation), pesticides and labor, combined with a possible increase in 
yield (Bernardo et al.,2019; Malavolta, 2006; Testezlaf, 2011; Vilas Boas et al., 2011).

In view of the above, the objective of this study was to evaluate the production of pout pepper cultivated under irrigation depths and $\mathrm{N}$ doses in Latossolo Vermelho (Oxisol) of the Cerrado region.

\section{Results and discussion}

For the variables fresh and dry weights of fruits per plant, number of fruits and yield per plant, there were significant differences caused by $\mathrm{N}$ doses, as can be observed in Table 1. For water productivity, there was significant interaction between irrigation depths and $\mathrm{N}$ doses.

\section{Effect of nitrogen doses on the fresh and dry mass of pout pepper}

For fresh weight of fruits per plant, there was a significant difference caused by $\mathrm{N}$ doses, and the data were described by a quadratic polynomial regression model (Figure 2). The highest fresh weight of fruits $\left(873.95 \mathrm{~g} \mathrm{plant}^{-1}\right)$ was observed with $\mathrm{N}$ dose of $141.66 \mathrm{~kg} \mathrm{ha}^{-1}$, which represented a $46.67 \%$ increase in the fresh weight of fruits compared to the treatment without $\mathrm{N}$ application.

In a study for agronomic and pungency characterization of peppers of the genus Capsicum, Domenico et al. (2012) observed a lower yield per plant than that observed in the present study with the cultivar 'IAC 1643' of pout pepper, 526.4 g plant $^{-1}$, confirming the importance of the supply of $\mathrm{N}$ fertilization for gains in fruit production. In a study carried out with $\mathrm{N}$ and soil water tensions in the cultivation of fertigated bell pepper in a greenhouse, Santos (2019) verified that there was a significant difference for soil water tensions and $\mathrm{N}$ doses, with an optimal $\mathrm{N}$ dose of $256.09 \mathrm{~kg}$ $\mathrm{ha}^{-1}$ for bell pepper, which is not similar to the result found in this study. In a study conducted by Kuscu et al. (2016) with pepper under fertigation with $\mathrm{N}$ doses, there was a significant effect of irrigation depths and also $\mathrm{N}$ doses. Similar results were also observed by Bhuvaneswari et al. (2014).

In a study on the effect of irrigation depths, using data of crop evapotranspiration, Marinho et al. (2016) observed a significant effect with linear response on the fresh weight of fruits per plant of tabasco pepper, not corroborating this study, which did not find significant differences caused by irrigation depths.

For the dry weight of fruits per plant of pout pepper, there was a significant difference caused by $\mathrm{N}$ doses, and a quadratic polynomial regression model fitted to the data (Figure 3). The $\mathrm{N}$ dose of $121.64 \mathrm{~kg} \mathrm{ha}^{-1}$ led to the highest dry weight of fruits ( $133.03 \mathrm{~g} \mathrm{plant}^{-1}$ ), and this value represented a $44.52 \%$ increase in comparison to plants with no $\mathrm{N}$ fertilization.

The observed results corroborate those reported by Simon and Tesfaye (2014), who found significant differences between $\mathrm{N}$ doses in the field cultivation of bell pepper in southern Ethiopia. Significant results for dry weight of fruits were also observed by Molla et al. (2019) in Ethiopia.

In a study conducted with variation in the percentages of crop evapotranspiration in the development of bell pepper in Venezuela, Padrón et al. (2015) observed no significant differences in the dry weight of the fruits between the irrigation depths, corroborating the results observed in the present study.
Effect of nitrogen doses on the number of fruits of the pout pepper

For the number of fruits per plant there was a significant difference caused by $\mathrm{N}$ doses, and the data were described by a quadratic polynomial regression model (Figure 4). The $\mathrm{N}$ dose of $138.77 \mathrm{~kg} \mathrm{ha}^{-1}$ promoted the highest number of fruits per plant (319), increasing the number of fruits by $28.85 \%$ in comparison to plants subjected to the absence of $\mathrm{N}$ fertilization.

Carneiro et al. (2016), studying the pout pepper cultivar 'Iracema' subjected to levels of $\mathrm{N}$ fertilization in the field, reported significant differences in the number of fruits and fit of a quadratic polynomial regression model, with maximum point at the $\mathrm{N}$ dose of $180 \mathrm{~kg} \mathrm{ha}^{-1}$. Similar results were also observed by Khan et al. (2014) and Alhrout (2017). Regarding water supply, the results corroborate those reported by Azevedo et al. (2015), who studied the effect of irrigation depths as a function of crop evapotranspiration on tabasco pepper and also found no significant differences in the number of fruits per plant.

\section{Effect of nitrogen doses on the yield of pout pepper}

The yield of pout pepper fruits was significantly affected by $\mathrm{N}$ fertilization, and the data was described by a quadratic polynomial regression model (Figure 5). The $\mathrm{N}$ dose of 141.4 $\mathrm{kg} \mathrm{ha}^{-1}$ enabled a production of $14,939.25 \mathrm{~kg} \mathrm{ha}^{-1}$ of fruits, and this value represented a $30.38 \%$ increase in comparison to that found in plants without $\mathrm{N}$ fertilization.

The results of the present study corroborate those of Aminifard et al. (2012), who studied bell pepper cultivated in the field under $\mathrm{N}$ doses in Iran and found significant differences for fruit yield, as well as Aticho et al. (2014), in cultivation in Ethiopia, Júnior et. al (2017) and Toungos et al. (2018). A study conducted with habanero pepper (Capsicum chinense Jacq.), in Mexico, found significant differences as a function of $\mathrm{N}$ levels (Santiago et al., 2015).

With the results of the present study, it is observed that $\mathrm{N}$ is required by pout pepper up to an optimal dose, and the plant can express its maximum production potential under the application of the ideal dose of a nutrient. Thus, nutritional supply may not be a limiting factor to crop yield (Costa et al., 2015).

The result of this study can serve as a reference for $\mathrm{N}$ management for pepper plants in the region because, in order to produce any vegetable with quality and in large quantity, it is necessary to provide the soil with all the nutrients needed by the plant for its development, especially in periods of greater nutritional requirement (Morais et al., 2017).

\section{Effect of irrigation depths and nitrogen doses on water productivity}

Water productivity was significantly affected by the interaction between irrigation depths and $\mathrm{N}$ doses, with a point of minimum on the response surface (Figure 6). At the stationary point, with irrigation depth equivalent to $118.3 \%$ ETc associated with $\mathrm{N}$ dose of $0 \mathrm{~kg} \mathrm{ha}^{-1}$, water productivity was equal to $7.13 \mathrm{~kg} \mathrm{~L}^{-1}$ of fresh fruits. The highest water productivity was obtained with the $40 \%$ ETc depth associated with a $\mathrm{N}$ dose of $240 \mathrm{~kg} \mathrm{ha}^{-1}$, being equal to 9.31 $\mathrm{kg} \mathrm{L}^{-1}$, resulting in a $23.41 \%$ increase in comparison to the water productivity at the stationary point.

Cardozo et al. (2016), in a study with bell pepper, observed results similar to those obtained in the present study for water productivity, which decreased with the increase of 
Table 1. Analysis of variance for fresh weight of fruits per plant (FWF), dry weight of fruits per plant (DWF), number of fruits per plant (NF), plant yield (PY) and water productivity (WP) of pout pepper cv. 'BRS Moema'.

\begin{tabular}{llllll}
\multirow{2}{*}{ Factor of variation } & \multicolumn{5}{l}{} \\
\cline { 2 - 6 } & $\mathrm{FWF}$ & $\mathrm{DWF}$ & $\mathrm{NF}$ & $\mathrm{PY}$ & $\mathrm{WP}$ \\
\hline Block & 0.9513 & 0.9425 & 0.7286 & 0.9513 & 0.9513 \\
$\mathrm{~L}$ & $0.000^{* *}$ & $0.006^{* *}$ & $0.001^{* *}$ & $0.000^{* *}$ & $0.000^{* *}$ \\
Linear & $\mathrm{ns}$ & $\mathrm{ns}$ & $\mathrm{ns}$ & $\mathrm{ns}$ & $0.000^{* *}$ \\
Quadratic & $\mathrm{ns}$ & $\mathrm{ns}$ & $\mathrm{ns}$ & $\mathrm{ns}$ & $0.000^{* *}$ \\
\hline $\mathrm{N}$ & $0.016^{*}$ & $0.035^{*}$ & $0.018^{*}$ & $0.016^{* *}$ & $0.000^{* *}$ \\
$\quad$ Linear & $0.001^{* *}$ & $0.002^{* *}$ & $0.002^{* *}$ & $0.001^{* *}$ & $0.011^{*}$ \\
Quadratic & $0.005^{* *}$ & $0.002^{* *}$ & $0.004^{* *}$ & $0.005^{* *}$ & 0.1543 \\
\hline L x N & 0.1024 & 0.2934 & 0.2020 & 0.1024 & $0.0037^{* *}$ \\
\hline Overall Mean & 592.24 & 89.05 & 281.75 & 13160.91 & 49.06 \\
C.V.1 (\%) & 88.36 & 95.54 & 74.35 & 88.36 & 65.13 \\
C.V.2 (\%) & 35.31 & 41.66 & 34.07 & 35.31 & 30.59 \\
Lambda $(\lambda)$ & - & 0.5 & - & - & 0.5 \\
\hline Shapiro-Wilk (p-value) & 0.002 & 0.758 & 0.06681 & 0.02247 & 0.6011 \\
Bartlett & 0.235 & 0.671 & 0.066 & 0.678 & 0.639 \\
(p-value) & & & & & \\
\hline
\end{tabular}

** significant at $1 \%$ probability level $(p<0.01) ;{ }^{*}$ significant at $5 \%$ probability level $(0.01 \leq p<0.05) ;{ }^{\text {ns }}$ not significant at $p \geq 0.05 ; C . V$. Coefficient of variation; Lambda $(\lambda)$ transformation factor of the Box-Cox family model. L: irrigation depths; $\mathrm{N}$ : nitrogen doses.

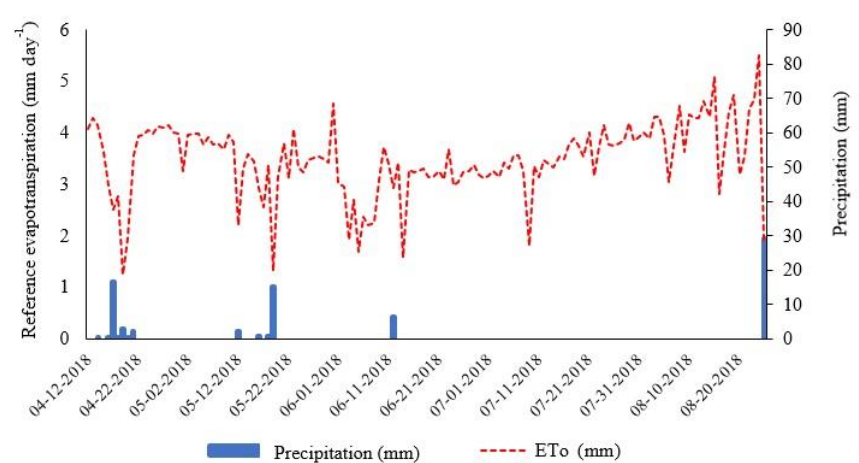

Fig 1. Reference evapotranspiration (ETo) and precipitation values in the period from $04 / 12 / 2018$ to $08 / 25 / 2018$, at the INMET station of Rondonópolis - MT. Fonte: http:/inmet.gov.br.

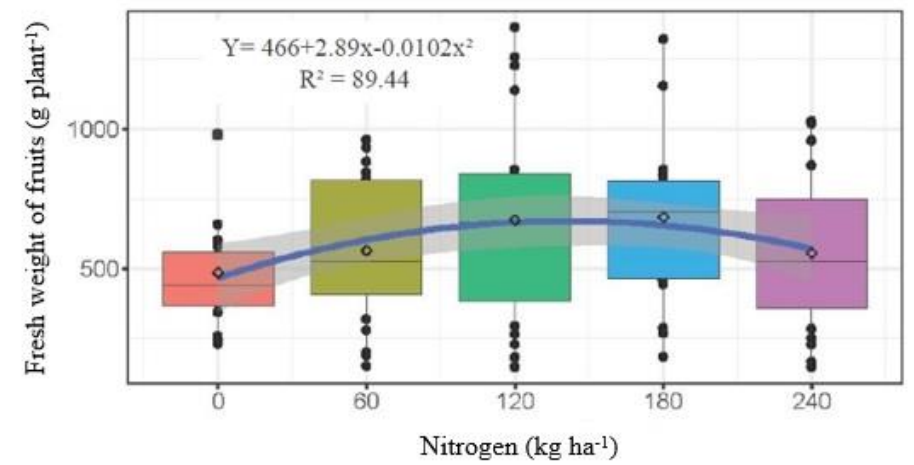

Fig 2. Fresh weight of fruits of pout pepper cv. 'BRS Moema', as a function of nitrogen doses.

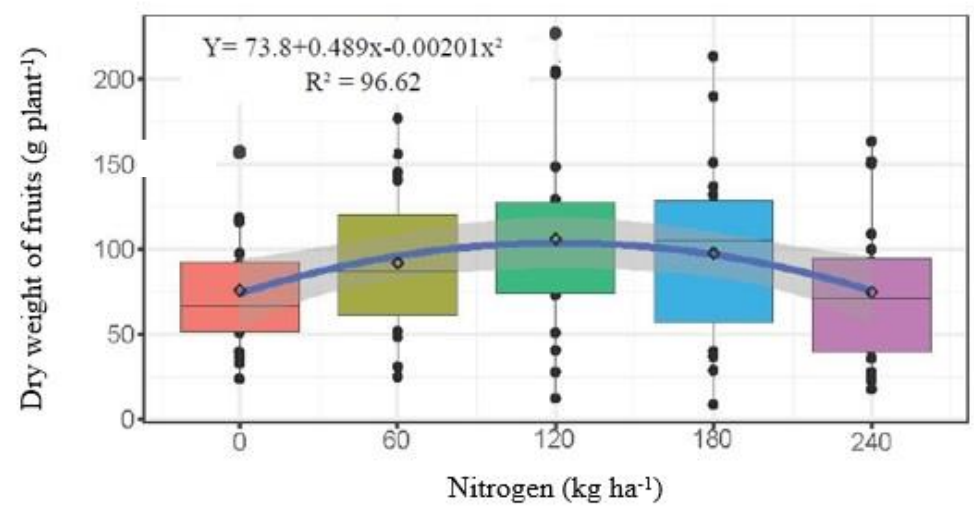

Fig 3. Dry weight of fruits of pout pepper cv. 'BRS Moema', as a function of nitrogen doses. 


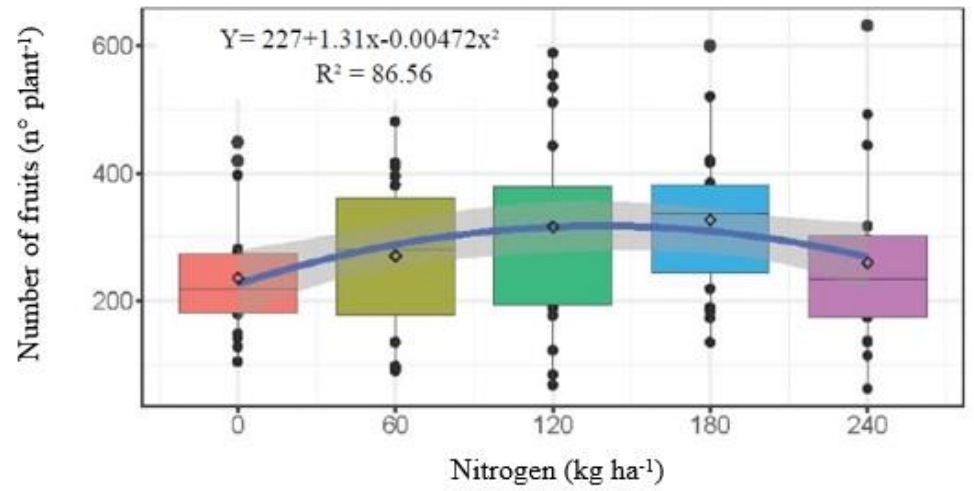

Fig 4. Number of fruits per plant of pout pepper cv. 'BRS Moema', as a function of nitrogen doses.

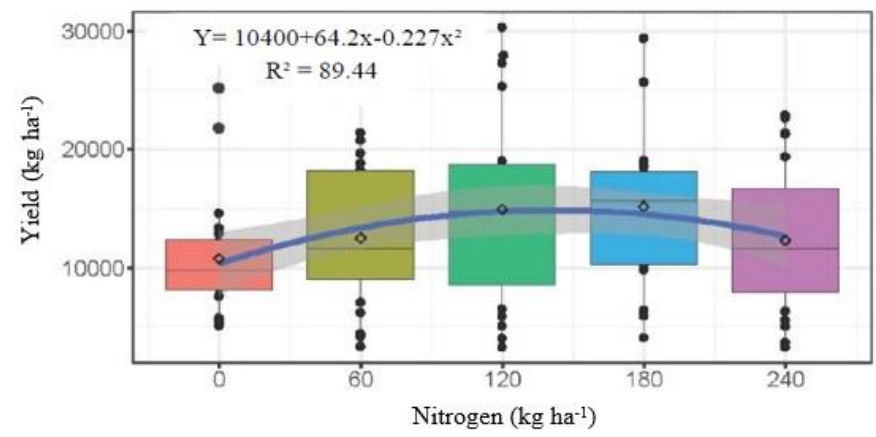

Fig 5. Fruit yield of pout pepper cv. 'BRS Moema', as a function of nitrogen doses.

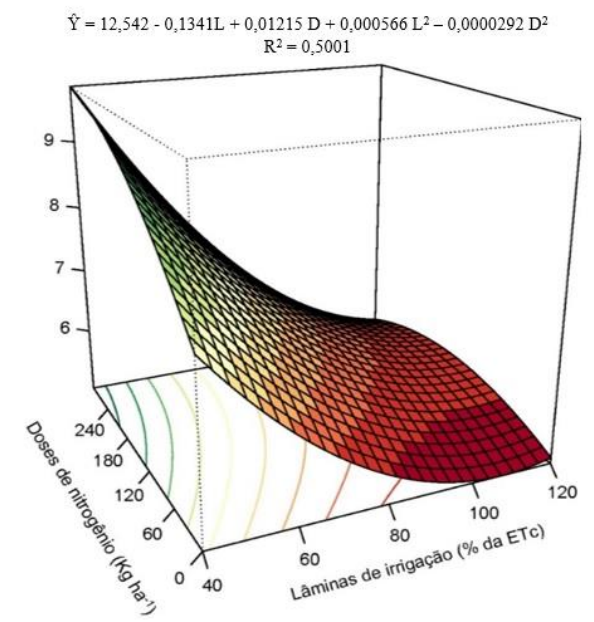

Fig 6. Water productivity by pout pepper cv. 'BRS Moema', as a function of nitrogen doses and irrigation depths, after the end of the ripe fruit harvest period.

water replacement in the soil. The results of this study also corroborate those reported by Júnior et al. (2015), who studied the effect of irrigation depths on tabasco pepper (Capsicum frutescens L.) and obtained the highest water productivity with the irrigation depth corresponding to $40 \%$ ETc. Similar results were also observed by Albuquerque et al. (2012) and Silva et al. (2019).

Aragão et al. (2012), evaluating the effect of irrigation depths and $\mathrm{N}$ doses on the cultivation of bell pepper, found that the highest water productivity was obtained with the $50 \%$ ETc depth associated with a $\mathrm{N}$ dose of $40 \mathrm{~kg} \mathrm{ha}^{-1}$. However, these authors emphasize that this variable is not related to fruit yield, being only a satisfactory response of the plant to water deficit, corroborating the present study. Santos (2019) observed a higher water productivity in the protected cultivation of bell pepper with a $\mathrm{N}$ dose of 239.5 $\mathrm{kg} \mathrm{ha}^{-1}$, corroborating the present study, when the variable is analyzed only as a function of $\mathrm{N}$ doses.

\section{Materials and methods}

\section{General information}

The experiment was conducted in the field, at the Federal University of Mato Grosso, Rondonópolis-MT, Brazil, at the geographic coordinates $16^{\circ} 27^{\prime}$ South latitude, $54^{\circ} 34^{\prime}$ West longitude and altitude of $289 \mathrm{~m}$. The climate of the region according to Köppen's classification is Aw, characterized as a tropical of dry winter and rainy summer (Dantas et al., 2007).

The experimental design was in randomized blocks, in a split plot scheme. The plots were composed of five irrigation depths $[40,60,80,100$ and $120 \%$ of ETc (crop 
evapotranspiration)] and the subplots consisted of five $\mathrm{N}$ doses $\left(0,60,120,180\right.$ and $\left.240 \mathrm{~kg} \mathrm{ha}^{-1}\right)$, with four replicates. The experimental unit was represented by the subplot, with dimensions of $2.7 \mathrm{~m} \times 2.5 \mathrm{~m}$, spacing of $0.5 \mathrm{~m}$ between plants and $0.9 \mathrm{~m}$ between rows, and the usable area was composed of the three central plants.

Soil samples were collected in the experimental area, in the 0-0.2 $\mathrm{m}$ layer, and had the following chemical and granulometric characteristics according to EMBRAPA (2011): $\mathrm{pH}\left(\mathrm{CaCl}_{2}\right)=4.8 ; \mathrm{P}=5.2 \mathrm{mg} \mathrm{dm}^{-3} ; \mathrm{K}=82 \mathrm{mg} \mathrm{dm}^{-3} ; \mathrm{Ca}=1.4$ $\mathrm{cmol}_{\mathrm{c}} \mathrm{dm}^{-3} ; \mathrm{Mg}=0.8 \mathrm{cmol}_{\mathrm{c}} \mathrm{dm}^{-3} ; \mathrm{Al}=0 \mathrm{cmol}_{\mathrm{c}} \mathrm{dm}^{-3} ; \mathrm{H}=2.7$ $\mathrm{cmol}_{\mathrm{c}} \mathrm{dm}^{-3} ; \mathrm{OM}=14.9 \mathrm{~g} \mathrm{~kg}^{-1} ; \mathrm{SB}=2.4 \mathrm{cmol}_{\mathrm{c}} \mathrm{dm}^{-3} ; \mathrm{CEC}=5.1$ $\mathrm{cmol}_{\mathrm{c}} \mathrm{dm}^{-3} ; \mathrm{V}=47.2 \%$; sand $=407 \mathrm{~g} \mathrm{~kg}^{-1} ;$ silt $=136 \mathrm{~g} \mathrm{ka}^{-1}$; and clay $=457 \mathrm{~g} \mathrm{~kg}^{-1}$.

Soil correction was performed by the base saturation method with elevation in base saturation to $80 \%$ through the application of dolomitic limestone (TRNV $86 \%$ ) according to Sousa \& Lobato (2004). Limestone was applied broadcast and then incorporated with a tractor-mounted light harrow to a depth of $30 \mathrm{~cm}$. The soil of the experimental area was classified as Latossolo Vermelho distrófico (Oxisol) (EMBRAPA, 2018).

Pout pepper seedlings were produced in a greenhouse, using the cultivar 'BRS Moema', with sowing in polyethylene trays. The seedlings were transplanted to the field 43 days after sowing with an average height of $8 \mathrm{~cm}$.

Fertilization with macro and micronutrients was adapted from that recommended for bell pepper, according to Ribeiro et al. (1999), due to the lack of specific recommendations for pout pepper. At the transplantation of the seedlings, in holes, the soil received the equivalent to 300,20 and $50 \mathrm{~kg} \mathrm{ha}^{-1}$ of phosphorus $\left(\mathrm{P}_{2} \mathrm{O}_{5}\right)$, sulfur $(\mathrm{S})$ and micronutrients in the form of FTE BR 12 (7.1\% Calcium, 5.7\% Sulfur, $1.8 \%$ Boron, 0.8\% Manganese, 0.1\% Molybdenum and $9.0 \%$ Zinc), respectively. Nitrogen and potassium fertilization were split according to the treatments and the recommended doses, being $0,60,120,180$ and $240 \mathrm{~kg} \mathrm{ha}^{-1}$ of nitrogen $(\mathrm{N})$ and $240 \mathrm{~kg} \mathrm{ha}^{-1}$ of potassium $\left(\mathrm{K}_{2} \mathrm{O}\right)$. At the time of transplanting, $20 \%$ of the recommendations of nitrogen $\left(\mathrm{CH}_{4} \mathrm{~N}_{2} \mathrm{O}\right)$ and potassium $\left(\mathrm{K}_{2} \mathrm{O}\right)$ were applied to the soil and the remainder was divided into 6 portions and applied along the crop development.

\section{Irrigation management}

The irrigation depths were applied by a drip irrigation system, composed of a water reservoir, 0.5-hp centrifugal pump, screen filter, exhaust valve and manometer. The irrigation pipes comprised drip tapes, with spacing of $0.1 \mathrm{~m}$ between emitters, each of which with flow rate of $1.2 \mathrm{~L} \mathrm{~h}^{-1}$ and pressure of 8 m.w.c.

Irrigation management was performed based on reference evapotranspiration (ETo), estimated by the PenmanMonteith equation (Equation 1), using as source meteorological data collected from the automatic station of INMET (National Institute of Meteorology), located $100 \mathrm{~m}$ away from the experimental area (Allen et al., 1996). Data of air temperature, relative humidity, wind speed, atmospheric pressure, precipitation and solar radiation were collected daily. Figure 1 shows the behavior of the data related to precipitation and ETo along the experimental period.

ETo $=\frac{0.408 \Delta(R n-G)+\gamma \frac{900}{T+273} U_{2}\left(e_{s}-e_{a}\right)}{\Delta+\gamma\left(1+0.34 U_{2}\right)}$

Where:

ETo - reference evapotranspiration $\left(\mathrm{mm} \mathrm{d}^{-1}\right)$; $\left.{ }^{1}\right)$;

$R n$ - net solar radiation ( $\left.\mathrm{MJ} \mathrm{m}^{-2} \mathrm{~d}^{-1}\right)$;

$G$ - soil heat flux (MJ $\mathrm{m}^{-2} \mathrm{~d}^{-1}$ );

$\gamma$-psychrometric constant $\left(\mathrm{kPa}^{\circ} \mathrm{C}^{-1}\right)$;

$U_{2}$ - wind speed $\left(\mathrm{m} \mathrm{s}^{-1}\right)$;

$e_{s}-$ saturation vapor pressure of atmospheric water $(\mathrm{kPa})$;

$e_{a}-$ actual vapor pressure of atmospheric water $(\mathrm{kPa})$;

During the experimental period, the highest and lowest values obtained for ETo were $5.5 \mathrm{~mm}$ and 1.26, respectively, with a cumulative total of $474.42 \mathrm{~mm}$. The total accumulated precipitation was $79.2 \mathrm{~mm}$, and this value was subtracted in the calculation of irrigation.

ETo was used to estimate ETc (crop evapotranspiration), by multiplying ETo by Kc (crop coefficient), which varied according to the development of the crop. After ETc was obtained, the time required for each irrigation was calculated daily, according to the treatments and efficiency of the irrigation system (90\%).

\section{Analysis of fruit production}

Ripe fruits began to be harvested at 90 days after transplanting the seedlings, and the harvested fruits were evaluated in a period of 45 days. All the fresh weight of fruits per plant was evaluated by measuring their weights on a semi-analytical scale. After being weighed, the fruits were manually counted to evaluate the number of fruits per plant. To obtain the dry weight of fruits per plant, the fruits were dried in a forced air circulation oven at $65{ }^{\circ} \mathrm{C}$ until they reached constant weight and then weighed on a semianalytical scale. Plant yield was obtained based on the total fruit yield per area. Water productivity was determined by the ratio between fresh fruit production and water volume applied.

The significance of the response surface model and the linear, quadratic and interaction terms were verified by the analysis of variance at $5 \%$ probability level by $\mathrm{F}$ test, as described by Cirillo (2015). When the criteria for selecting the response surface model were not met, the single effects of the factors were studied by polynomial regression analysis. Statistical analysis of the data was performed using the free software R statistical 3.4.2 ${ }^{\circledR}$ (R Core TEAM, 2018).

\section{Conclusions}

Adequate doses of nitrogen promote adequate development of pout pepper. For higher yields, number of fruits and fresh and dry weights of fruits, the ideal nitrogen dose is between 121 and $141 \mathrm{~kg} \mathrm{ha}^{-1}$.

The irrigation depths applied do not influence the development of plants, and water productivity responds best to the lowest depth applied.

\section{Acknowledgements}

The authors are grateful to CAPES (Coordenação de Aperfeiçoamento de Pessoal de Nível Superior) and CNPq (Conselho Nacional de Desenvolvimento Científico e Tecnológico).

\section{References}

Albuquerque FS, Silva EFF, Nunes MFFN, Souza AER. (2012) Biomass allocation and water use efficiency in fertigated sweet pepper. Eng Agri. 32 (2): 315-325. 
Allen RG, Pereira LS, Raes D, Smith M (1996) Crop evapotranspiration - Guidelines for computing crop water requirements - FAO Irrigation and drainage paper 56 . Rome, Italy.

Alhrout, HH (2017) Response of Growth and yield components of sweet pepper to tow different kinds of fertilizers under greenhouse conditions in Jordan. J Agric Sci. 9(10): 265-272.

Almeida RN, Ferraz DG, Silva AS, Cunha EG, Vieira JC, Souza TS, Berilli SS (2017) Utilização de iodo de curtume em complementação ao substrato comercial na produção de mudas de pimenta biquinho. Sci Agr. 18(1): 20-33.

Aminifard MH, Aroiee H, Ameri A, Fatemi H (2012) Effect of plant density and nitrogen fertilizer on growth, yield and fruit quality of sweet pepper (Capsicum annuum L.). Afri J Agric Res. 6 (6): 859966.

Aragão VF, Fernandes PD, Filho RRG, Carvalho CM, Feitosa HO, Feitosa EO (2012) Produção e eficiência no uso da água do pimentão submetido a diferentes lâminas de irrigação e níveis de nitrogênio. R Brasi de Agric Irri.6 (3): 207-216.

Aticho A, Tamirat M, Bantirgu A, Tulu S, Regassa A, Dume B (2014) Influences of mineral nitrogen and phosphorous fertilization on yield and contributing componentes in hot pepper (Capsicum annuum L.). Afri J Agric Res. 9 (7): 670-675.

Azevedo BM, Chavez SWP, Medeiros JF, Aquino BF, Bezerra FML, Viana TVA (2015) Rendimento da pimenteira em função de lâminas de irrigação. Rev Ciênc Agron. 36 (3): 268-273.

Bernardo S, Mantovani EC, Silva DD, Soares AA (2019) Manual de irrigação. 9 ed. Viçosa: Editora UFV, 545p.

Bhuvaneswari G, Sivaranjani R, Reetha S, Ramakrishan K (2014) Application of nitrogen fertilizer on plant density, growth, yield and fruit of bell peppers (Capsicum annuum L.). Int Lett Nat Sci. 8 (2): 81-90.

Cardozo MTD, Galbiatti JA, Santana MJ, Caetano MCT, Carraschi, SP, Nobile FO (2016) Pimentão (Capsicum annuum) fertilizado com composto orgânico e irrigado com diferentes lâminas de irrigação. Irriga .21 (4): 673-684.

Carneiro LB, Silva Junior RL, Carvalho FJ, Nascimento MV, Xavier RC, Benett KSS, Benett CGS, Costa E (2016) Effects of nitrogen fertilization and hydrorententor gel application in Capsicum spp. cultivation. Aust J Crop Sci. 10: 1399-1403.

Carvalho SIC, Bianchetti LB, Ribeiro CSC, Lopes CA (2008) Pimentas do gênero Capsicum no Brasil. Brasília: Embrapa Hortaliças, 27p.

Bosland PW, Votava EJ (2000) Peppers: vegetable and spice Capsicum. Berkeley: Ten Speed Press. 240p.

Cirillo MA (2015) Otimização na experimentação: aplicações nas Engenharias e Ciências Agrárias. In: UFLA (ed), Lavras.

Costa AR, Rezende R, Freitas PSL, Gonçalves ACA, Frizzone JAA (2015) Cultura da abobrinha italiana em ambiente protegido utilizando fertirrigação nitrogenada e potássica. Irriga. 20 (1): 105127.

Dantas AAA, Carvalho LG, Ferreira E (2007) Classificação e tendências climáticas em Lavras, MG. Cienc Agrotec. 31 (6): 18621866.

Domenico Cl, Coutinho JP, Godoy HY, Melo AMT (2012) Caracterização agronômica e pungência em pimenta de cheiro. Hortic Bras. 30: 466-472.

EMBRAPA - Empresa Brasileira de Pesquisa Agropecuária (2011) Manual de análise de solos. Brasília: EMBRAPA, 230p.

EMBRAPA - Empresa Brasileira De Pesquisa Agropecuária (2018) Sistema Brasileiro de Classificação de Solos, 5ạ edn. Brasília, DF.

Heinrich AG, Ferraz AG, Ferraz RM, Ragassi CF, Reifschneider FJB (2015) Caracterização e avaliação de progênies autofecundados de pimenta biquinho salmão. Hortic Bras. 33(4): 465-470.

Junior MV, Vasconcelos AJF, Lima LSS, Silva KF, Carvalho CM (2015) Eficiência do uso da água em pimenta da espécie Capsicum frutescens L., variedade tabasco. Appl Res Agrotec. 8 (2): 53-61.

Junior SN, Medeiros JF, Oliveira FA, Lima LA, Bezerra MS, Alves RC (2017) Nitrogen and potassium fertigation in bell pepper cultivated in greenhouse using fertigation managements. Rev Bras Eng Agric. 21 (3): 186-190.

Khan A, Shah SNM, Rab A, Sajid M, Ali K, Ahmed A, Faisal S (2014) Intl J Farm \& Alli Sci. 3 (3): 260-264.
Kuscu H, turhan A, Ozmen N, Aydinol P, Demir AO (2016) Response of red pepper to deficit irrigation and nitrogen fertigation. Arch Agron Soil Sci. 62 (10): 1396-1410.

Macedo A (2015) Pimentas Capsicum: uma história de sucesso na cadeia produtiva de hortaliças. Brasília: Embrapa Hortaliças, 11p.

Malavolta E (2006) Manual de nutrição mineral de plantas. São Paulo: Embrapa Meio Ambiente, 631p.

Marinho LB, Frizzone JA, Tolentinno Junior JB, Paulino J, Soares JM, Vilaça FN (2016) Déficit hídrico nas fases vegetativa e de floração da pimenta 'tabasco' em ambiente protegido. Irriga. 21 (3): 561576.

Mengel K, Kirkby EA (2001) Principles of plant nutrition. 5 ed. Springer Holanda. N. 26, 849p.

Molla T, Abera G, Beyene S (2019) Effects of Nitrogen Fertilizer and Mulch Application on Growth Performance and Pod Yields of Hot Pepper (Capsicum annum L.) under Irrigated Condition. Int J Plant \& Soil Sci. 27 (5): 1-15.

Morais GP, Gomes VFF, Mendes Filho PF, Almeida AMM de, Silva Junior JMT da (2017) Adubação nitrogenada associada à inoculação com Azospirillum brasilense na cultura do milho. Rev Agro Tec. 38: 109-116.

Padrón RAR, Ramírez LR, Cerquera RR, Nogueira HMCM, Mujica JLU (2015) Desenvolvimento vegetativo de pimentão cultivado com lâminas e frequências de irrigação. Tec \& Cienc Agro. 9 (2): 49-55.

Primavesi A (2002) Manejo ecológico do solo: a agritultura em regiões tropicais. São Paulo: Nobel, 549p.

R CORE TEAM (2018) R: A language and enviroment for statistical computing. R Foundation for Statistical Computing, Vienna, Austria. Available at: https://www.R-project.org/.

Ribeiro AC, Guimarães PTG, Alvarez VHV (1999) Recomendações para o uso de corretivos e fertilizantes em Minas Gerais - 5a aproximação. Viçosa, MG: Comissão e Fertilidade do Solo do Estado de Minas Gerais - CFSEMG: 360.

Ribeiro CSC, Lopes CA, Carvalho SIC, Henz GP, Reifschneider FJB (2008) Pimentas Capsicum. Brasília: Embrapa Hortaliças, 200p.

Santos HCA (2019) Nutrição nitrogenada na cultura do pimentão fertirrigado, em função de tensões de água no solo. Dissertação (Mestrado) - Programa de Pós-graduação em Agronomia (PPGA) Campus Universitário de Belém, Universidade Federal Rural da Amazônia.

Santiago GA, Esquivel GL, Hernández RS, Pérez ES, Paredes JDG, Meza VMJ (2015) Determination of the nitrogen requirement for habanero pepper (Capsicum chinense Jacq.). Rev Chapingo Ser Hortic. 21 (3): 215-227.

Serenini MJ, Malysz ST (2014) A importância da agricultura familiar na produção de alimentos. Cadernos PDE. 1: 28p.

Silva VF, Bezerra CV, Nascimento ECS, Ferreira TNF, Lima VLA, Andrade LO (2019) Production of chili pepper under organic fertilization and irrigation with treated wastewater. Rev Bras Eng Argic. 23 (2): 84-89.

Simon T, Tesfaye B (2014) Growth and productivity of hot pepper (Capsicum annuum L.) as affected by variety, nitrogen and phosphorous at Jinka, Southern Ethiopia. Res J Agric \& Environ Manage. 3: 427-433.

Sousa DMG, Lobato E (2004) Cerrado: Correção do solo e adubação. In: Embrapa Informação Tecnológica, 2nd edn, Brasília, DF.

Souza SAM, Martins KC, Pereira TNS (2011) Polimorfismo cromossômico em Capsicum chinense. Cienc Rural. 41: 1777-1783.

Taiz L, Zeiger E, Moller IM, Murphy A (2017) Fisiologia e desenvolvimento vegetal. 6. Ed. Porto Alegre: Artmed, 888p.

Testezlaf R (2011) Irrigação: Métodos, Sistemas e Aplicações. Faculdade de Engenharia Agrícola. Campinas, 205p.

Toungos M, Yahya R (2018) Performance of Sweet Pepper (Capsicum annum L.) under Five Levels of Nitrogen Fertilizer in Zaria, Kaduna State, Nigeria. Asian J Adv Agric Res. 5 (4): 1-7.

Vilas Boas RC, Pereira GM, Reais RP, Junior JAL, Consoni R (2011) Viabilidade econômica do uso do sistema de irrigação por gotejamento na cultura da cebola. Ciênc e Agrotec. 35 (4): 781788. 